\title{
A tecelagem lírica de uma Penélope moderna A Alquimia dos nós, de Yêda Schmaltz
}

\author{
Paulo Antônio Vieira Júnior ${ }^{1}$
}

Eros dociamargo

Eros que atormenta

Eros tecelão de mitos.

Safo de Lesbos

\begin{abstract}
RESUMO: A alquimia dos nós (1979), de Yêda Schmaltz, reinventa o mito de Penélope sob registro de Homero, na Odisseia. Através de uma visão feminina, a voz lírica constante no livro, sobretudo na primeira parte, "Fios (O livro de Penélope)", desenvolve o relato lírico da sua união com Ulisses, do período em que sofre a ausência do esposo e do retorno dele. A principal modificação na identidade da Penélope yediana decorre da reflexão e do tratamento em relação a sua sexualidade, bem como do desencanto ao divisar o homem amado, quando ele retorna. Os versos que integram essa obra não raro usam da metáfora da tecelagem e do tecido para caracterizar a voz lírica como pertencente à heroína do passado mitológico. Porém, a tecelagem metafórica também alude à sexualidade solitária de Penélope, bem como à atividade por ela exercida, o trabalho com o fio e a escrita poética. O presente estudo empreende leitura dos versos da poeta goiana a partir das considerações desenvolvidas sobre a metáfora da tecelagem e da consciência erótica do literário desenvolvidas por Hughes Liborel (1997), Ana Maria Machado (2001), Octavio Paz (2001) e Angélica Soares (1999).
\end{abstract}

\section{PALAVRAS-CHAVE: Yêda Schmaltz, fios, tecelagem, Penélope, erotismo.}

ABSTRACT: A alquimia dos nós (1979), of Yêda Schmaltz, reinvents the myth of Penelope in Homer's record, in the Odisseia. Through a female view, the constant lyrical voice in the book, especially in the first part, "Fios (O livro de Penélope)," develops the lyrical account of his union with Odysseus, the period suffering the absence of her husband and his return. The main change in the identity of Penelope from Schmaltz arises from reflection and treatment in relation to her sexuality and disenchantment to descry the beloved man when he returns. The verses that compose this work, often use the metaphor of weaving and fabric to characterize the lyrical voice as belonging to the heroine of the mythological past. But the metaphoric weaving also alludes to Penelope's lonely sexuality and to the activity exercised by her, work with ingrain and poetic writing. This study undertakes reading the verses of Schmaltz from the considerations set on the metaphor of weaving and literary erotic consciousness developed by Hughes Liborel (1997), Ana Maria Machado (2001), Octavio Paz (2001) and Angélica Soares (1999).

KEYWORDS: Yêda Schmaltz, ingrain, weaving, Penelope, eroticism.

Nascida em 8 de novembro de 1941 e falecida em 10 de maio de 2003, Yêda Schmaltz deixou uma obra significativa para a cultura goiana e representativa para a literatura de autoria feminina, no Brasil. Escreveu poesia, contos, ensaios sobre arte, literatura e manifestações culturais, trabalhou como professora universitária, artista plástica, dirigiu o Instituto Doutor pela Universidade Federal de Goiás. Professor Temporário da Universidade Estadual de Goiás. Email: <pauloantvie@hotmail.com>. 
Goiano do Livro, atuou na edição de suplementos culturais de jornais locais e participou da fundação do GEN (Grupo de Escritores Novos), movimento de renovação da literatura produzida em Goiás. Viveu pela cultura, converteu o que viveu e leu em criação poética.

A produção de Yêda Schmaltz que despertou maior atenção dos leitores e da crítica especializada é aquela em que a autora conseguiu expressar sua voz lírica mais singular através da reinvenção de personagens da mitologia greco-latina. Tais obras constituem as produções em verso da autora que encontram no erotismo seu tema nuclear: A alquimia dos nós (1979), Baco e Anas brasileiras (1985) e A ti, Áthis (1988). Elas ainda têm em comum a reinvenção de personagens históricas, lendárias e mitológicas, a exemplo de Penélope, Dioniso, Eco, Narciso, Apolo, Bacantes, Sulamita, Safo, Áthis e Cibele. Os versos que compõem as obras supramencionadas são motivados pela fábula erótica de personagens cristalizadas no imaginário da cultura ocidental, em decorrência das intempéries ocasionadas pela relação passional que viveram. No presente estudo, a abordagem da obra yediana deter-se-á sobre o quinto livro publicado pela escritora, A alquimia dos nós, mais especificamente a primeira parte em que se tem atualizado o mito de Penélope e das fiandeiras, tecelãs ou costureiras.

A alquimia dos nós é a obra em verso em que pela primeira vez Yêda Schmaltz estabeleceu o discurso mitopoético em sua produção literária, o que ocorre mais especificamente na primeira parte do livro, intitulada "Fios (O livro de Penélope)". O que chama a atenção nessa obra é não só a incorporação do discurso mitológico, mas a pluralidade de vozes líricas no interior dos poemas, as quais ora adquirem dicção de heroína típica da antiguidade, ora assumem um discurso de uma personagem que não se pode precisar. A voz central mais constante nos versos dessa parte do livro é, conforme indica o título, a heroína homérica Penélope, esposa de Ulisses. A heroína, nos versos da poeta goiana, sofre reconfigurações, em especial no concernente aos sentimentos que nutre pelo esposo, pois comunica enfaticamente seus anseios em relação ao amado, usando da metáfora da tecelagem para comunicar o envolvimento erótico, paralelamente, isso coloca-se como uma reflexão sobre o próprio fazer poético.

A alquimia dos nós (1979) é dividida em seis partes: "Fios ( $O$ livro de Penélope)", "Laços (Moja Bieda)", "Rédeas (O canto do cavalo)", "Cordas (Poemas de Paraúna)", a quinta parte não é nomeada, apresentando um traço e um parênteses vazio, e a última, "Arre-mate (Nó Górdio)". Conforme o título e os subtítulos indicam, o tema do fio, dos laços, das cordas, enfim, a atividade de tecer e amarrar são bastante recorrentes na obra.

A alquimia, retomada na nomenclatura do livro, é precursora da ciência química e na antiguidade tinha como objetivo a transformação de objetos inúteis em ouro, na modificação da natureza do lixo em pedra filosofal. Cloves Trindade Lopes (1989) percebeu já na nomeação da obra uma referência à Penélope, personagem da Odisseia, de Homero. Especialmente porque a função de fiandeira, exercida pela heroína da epopeia grega, é retomada no livro para o desenvolvimento dos poemas.

O termo "nós", reiteradamente repetido nas composições, é um modo de reafirmar o projeto estético do livro, pautado sobre o tema do erotismo, da união amorosa e da separação das personagens Ulisses e Penélope, da longa espera desta pelo esposo e da sua relação com as atividades de tecer, costurar, para sublimar a ausência do amado. Nessa estrutura, o

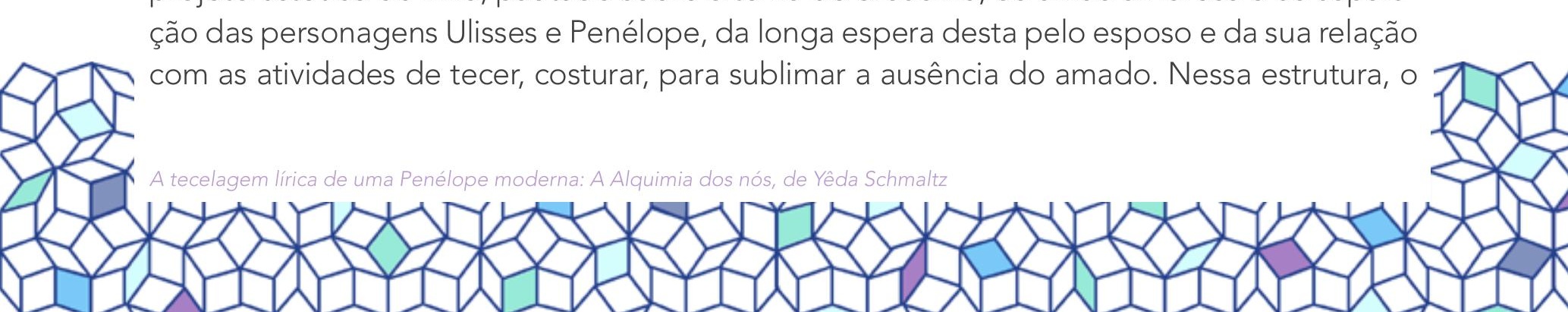


erotismo e a costura atravessam insistentemente não só a temática do livro, mas também a linguagem, uma vez que, ao comunicar o amor pelo homem amado, o eu lírico igualmente comunica seu amor pela poesia, a estreita relação que mantém com essa arte, tudo isso através de uma linguagem que lembra as circunvoluções da linha no tecido cosido:

Considerando ser essa obra uma "verdadeira alquimia de amor a laços", haja vista, especialmente sua primeira parte, o tema surge em todo o seu percurso. Esse referencial existe como representação da linha com que a mulher costura. Certamente o ato de costurar, criar novas realidades através da agulha e da linha, tem analogia com o fato de tecer a própria existência, pois a mulher, no seu potencial de geratriz, é o maior arquétipo da vida. (LOPES, 1989, p. 24)

Assim, a obra assemelha-se a um grande tecido no qual estão cerzidos o erótico, o mitológico, a louvação da arte poética e a autoafirmação da mulher acerca de seus desejos. "O livro de Penélope" possui 21 poemas, alguns divididos em até três ou quatro partes. Desse total, 12 trazem já no título das composições menções à atividade da costureira ou tecelã e a objetos ligados ao seu labor: "Linha azul", "A fiandeira", "Fios", "Nós", "Fio da meada", "O bordado", "O tecido", "O tapete", "Tear", "Agulha", "Vestido de lágrima" e "O bordado de Penélope". Já os títulos das outras nove composições sinalizam envolvimento erótico ("As núpcias", "O tempo da graça e a fala do amor", "A beleza do homem e seus apetrechos"), ou aludem à Odisseia, de Homero ("Sereias", "Navios"). A última sequência, intitulada "EspeIho", tende a comunicar o encontro/desencontro e o desenlace amoroso do casal mitológico.

Vera M. Tietzmann Silva (1990) observa ser o trabalho manual com o fio uma função ligada à imagem feminina, assim, o tema do fio presente na poesia da autora:

é de natureza essencialmente feminina, porque pressupõe atividades exercidas no recesso doméstico pela mão da mulher: fiar, tecer, costurar, bordar, cerzir, remendar. É um ato de criação de novas realidades (panos, roupas, tapetes), de transfiguração do velho em novo (cerzidos, remendos) ou do insípido em belo (bordados, acabamentos), tanto em função utilitária, como meramente decorativa. (TIETZMANN SILVA, 1990, p. 176)

A consideração da professora Tietzmann, que pode figurar como uma crítica essencialista, tem em mira o fato de que a dinâmica imaginária do mito das Fiandeiras esteve atrelada, na história da literatura e da cultura ocidental, à ideia de "feminilidade", na qual se reconhecia a fiação como atividade doméstica habitual, realizada predominantemente ao final do dia, favorecendo o canto e a narração das artesãs. Essa atividade era considerada, ainda, em sua natureza, correspondente à forma do corpo feminino, uma vez que à fiandeira, como à mulher, é atribuída a capacidade criadora, geratriz de novos objetos e seres. Assim, encontrava-se uma correlação entre a atribuição da natureza e os traços culturais. Essa visão foi reformulada no último século, dado que a atividade artesanal das tecelãs e fiandeiras já não se encontra mais atrelada à imagem feminina como outrora, inclusive porque se assistiu

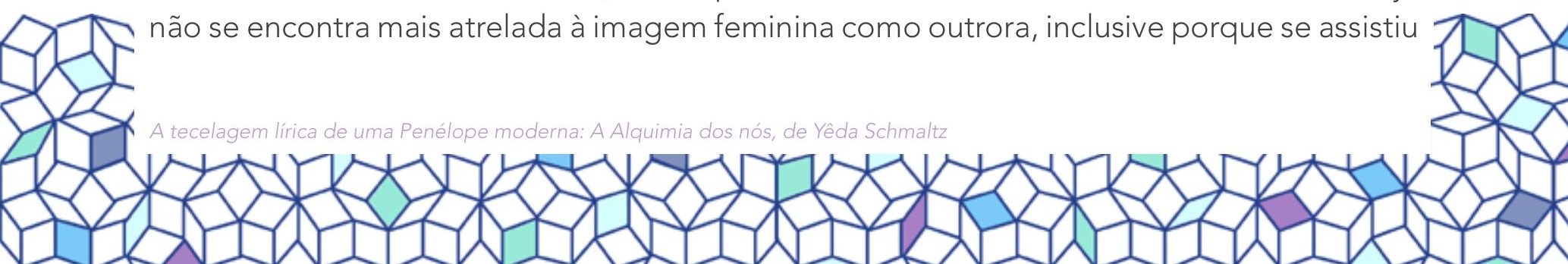


ao ocaso das atividades artesanais, paralelamente ao ingresso da mulher em segmentos diversos do mercado de trabalho. Yêda serviu-se dessa tradição do passado em busca de uma voz lírica própria. Nos livros anteriores, a poeta já havia manifestado seu anseio de reformulação de seus princípios poéticos. No livro em questão a autora consegue construir essa voz ao retornar ao passado mitológico, participar das concepções daquele meio e no interior dele subverter suas visões cristalizadas.

O simbolismo do fio, conforme explica Hughes Liborel (1997, p. 383), encontra-se intimamente ligado à palavra escrita e à assunção de uma voz pessoal, porque "a voz, como o fio, é representação ambivalente do passado e do presente". $\bigcirc$ fio tornou-se, portanto, culturalmente amalgamado à voz, o que ocorreu devido ao fato de frequentemente o trabalho das artesãs ser acompanhado de narrativas, sonhos, poesias, melodias e canções populares. Pode-se dizer, nesse sentido, que a voz passou a alimentar a meada do fio e, consequentemente, a escrita também, pois "[a] voz segue um desenrolar e marca com sua assinatura os encontros da pessoa consigo própria, ou com ouvintes-leitores que, ao escutá-la, reconhecerão, sem sombra de dúvida, a voz do autor".

A correlação da matéria têxtil com o texto é recorrente. Essa correspondência é frequentemente aludida em faculdades de Letras, por exemplo, quando a terminologia do universo das fiandeiras é empregada na elaboração da escrita. É comum, então, circular expressões a exemplo das que orientam que o texto precisa ser "amarrado", "ter suas pontas cortadas", ter as "ideias costuradas" ou que a palavra "perdeu o fio da meada". Liborel explica essa transformação da linguagem em "fio da palavra" ou da "linguagem numa enfiada" através da expressão "um filete de voz":

A locução 'um filete de voz' convida-nos a uma outra abordagem quanto ao simbolismo do fio que fiaria a própria voz, representação daquilo que em nós sairia do obscuro, seria o rastro, o sinal mais autobiográfico de quem ousa olhar-se interiormente. Os signos vocais, mais do que o olhar, nos escreveriam incessantemente, e a voz, o filete de voz seria o autorretrato mais perfeito do self. Para que uma pessoa se diga inteiramente às outras e para que essas outras aprendam a dizer-se também, seria preciso que começássemos o canto do self pelas encantações do self. (LIBOREL, 1997, p. 383)

É nesse sentido que percebemos que, a partir de $A$ alquimia dos nós, Yêda Schmaltz encontrou sua voz lírica mais singular. Essa voz lírica surge de um processo de despersonalização, em que a poeta recorre a personas retiradas da mitologia clássica e da história da cultura ocidental, usando delas para cavar mais fundo em sua subjetividade. $\bigcirc$ uso de máscaras poéticas, portanto, franqueou à autora espaço para dizer-se inteiramente. Logo, os poemas eróticos mais bem realizados da autora são justamente aqueles em que a poeta fala através de outras personagens.

O fio, o tecer, a costura e o bordado estão presentes não só na temática dos poemas de A alquimia dos nós, mas também nas estratégias de composição dos versos, na estrutura do livro e das composições, pelo movimento de ida e volta de imagens e temas, assim

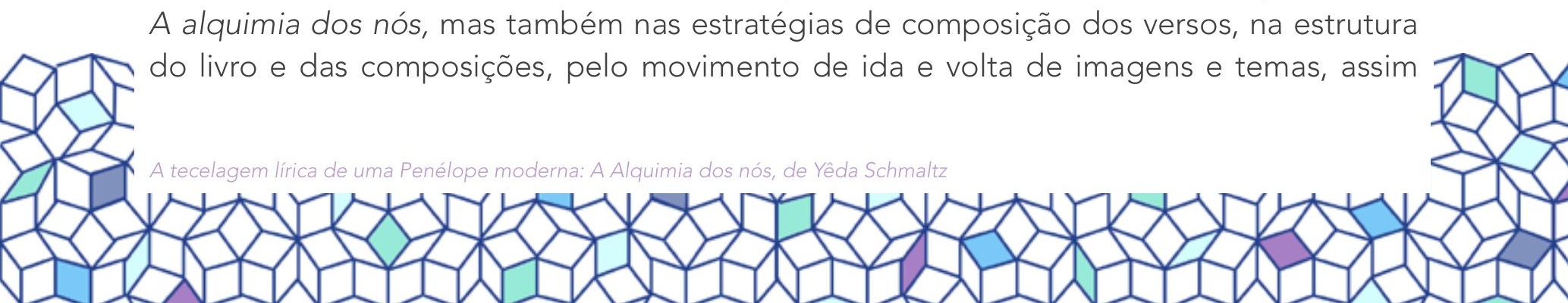


como pela adição de outros discursos ao da obra. O livro figura, então, como produto de uma costura realizada pela escritora-artesã, que borda outros discursos ao seu. Nesse processo, a intertextualidade é abundante na obra, através de diálogos diretos, nos quais são transcritos textos de autores como Malcolm Chazal, Nietzche, Nise da Silveira e Homero; através de diálogos indiretos constituídos por meio da citação ou alusão (a Bíblia, Descartes); e por meio de diálogos com textos não verbais, a exemplo do quadro de Ticiano na capa e as fotografias e quadros que ilustram o livro, elementos que intervém no significado dos textos e do livro como um todo. Isso demonstra que para Yêda Schmaltz a escrita se faz com (várias) leituras, em um processo semelhante ao da fiação, no qual instrumentais de ordem diversa conjugam-se na construção de outro elemento, nesse caso, o tecido poético.

Isso decorre, sobretudo, da intenção da poeta de produzir uma obra lírica pautada sobre a autoafirmação feminina. As atividades retomadas e os utensílios usados como matéria poética estão ligados ao uso doméstico das mulheres da antiguidade. Conforme as pesquisas arqueológicas demonstraram, "as mulheres do lar, bem antes do final do quinto milênio antes de Cristo, [já] fiavam e teciam" (LIBOREL, 1997, p. 371), sendo essa a principal ocupação feminina durante muitos séculos. Do círculo das fiandeiras, os homens deveriam estar sempre afastados. Liborel registra até mesmo a existência de uma tradição europeia, no medievo, na qual a noiva era sempre presenteada com uma roca de madeira pelo futuro esposo.

As fiandeiras, na atividade laboral que exerciam, puderam construir outro mundo, pois por meio do trabalho manual com o fio extravasavam os limites ao qual estavam condicionadas, através do sonho solitário ou coletivo, quando cantavam, evocavam idílios, narravam estórias para o entretenimento das companheiras. Com isso, encontraram um vínculo entre o trabalho concreto e o abstrato, respectivamente, o tecido e os sonhos. Yêda reconhece esse vínculo e extravasa seus limites ao apontar correspondências entre a produção da poesia e do tecido.

De fato, essas foram atividades às quais a autora dedicou-se com afinco, especialmente nos anos 1970. Deles resultaram bordados de diversos tipos, construídos por ela mesma, que adornavam espaços diversos de sua residência, e os poemas publicados na primeira parte de A alquimia dos nós. Yêda uniu arte e bordado, ainda, em um quadro-mosaico ${ }^{2}$ que apresenta diversos estilos de bordados, nesse quadro estão conjugadas funções caras à autora, a arte e o trabalho manual. Essas informações biográficas, por sua vez, são interessantes por revelar a obsessão da autora pela heroína homérica, ao longo dos anos 70. Tanto que, parte dos poemas contidos em "Fios ( $\bigcirc$ livro de Penélope)" foram esporadicamente publicados pela autora em coletâneas, antologias e revistas trazendo a assinatura de "Penélope" 3.

Assim, o fio torna-se vínculo e caminho para a produção artística, o que é significativo porque as fiandeiras serviram de musas para a literatura, a pintura e a música, além de terem sido responsáveis pela fabricação do tempo e pelo desenvolvimento da vida humana, conforme atribuição das Moiras, Graças e Horas, na mitologia clássica greco-romana.

2 Esse quadro integra hoje o acervo particular de uma das filhas da autora. O poema "O arremate" (SCHMALTZ, 1979, p.182), ao final do livro em estudo, parece fazer referência a esse quadro-mosaico.

Um exemplo disso é a coletânea Poesia e contos Bacharéis II (TELES, 1976), que traz entre as produções de Yêda Schmaltz ali contidas quatro poemas inéditos, que posteriormente foram incluídos em "Fios (O livro de Penélope)", de A alquimia dos nós, são eles: "AguIha", "Tear", "O tempo da graça e a fala do amor" e "A beleza do homem e seus apetrechos". 
"Fios (O livro de Penélope)" possui uma disposição dos poemas que permite entender que ali se encontra a história recontada da heroína de Homero, através de uma visão feminina e feminista em que a obra épica torna-se lírica. Penélope, na Odisseia, figura como emblema de fidelidade conjugal, enquanto na obra yediana apresentam-se outras características da heroína. Assim, em Homero, "Penélope, como personagem, é bem mais plana e menos atraente do que Ulisses, cujas vicissitudes e tribulações o leitor acompanha passo a passo" (TIETZMANN SILVA, 1990, p. 182). Em A alquimia dos nós, Penélope surge como uma personagem principal, enquanto Ulisses adquire contornos vagos e imprecisos. É possível verificar esse fenômeno na representação de três perfis de Penélope na obra yediana. A primeira delas é a surgida em um discurso amoroso que a torna suscetível a Ulisses; na sequência, Penélope empreende um afastamento da figura do esposo. Esse afastamento, que já era físico, progride para o distanciamento sentimental, ao erotizar aspectos de sua vida cotidiana e neles encontrar, de modo solitário, êxtase semelhante ao vivenciado na união com o homem amado. Por fim, a heroína adquire independência plena em relação a Ulisses, recusa a ele se entregar, no restante da obra parte em busca de outras vivências eróticas, isto é, a partir da segunda seção de A alquimia dos nós, a voz lírica é caracterizada pelo erotismo errante, não mais se atém unicamente a Ulisses. Desse modo, o trabalho manual com o fio promove a emancipação identitária e sexual de Penélope.

Essa transformação sofrida pela personagem é sinalizada no primeiro poema do livro, "Bicho de seda". Esse poema pode ser visto como uma referência a Penélope porque, segundo Hughes Liborel (1997, p. 374), "a fiandeira é meio mulher meio bicho", em decorrência da ligação do mito com a fábula de Aracne, bem como a atividade da fiandeira assemeIha-se à de Aracne. Penélope, como a aranha, trabalha noite e dia em sua teia para sublimar a ausência do esposo e enganar os pretendentes. $\bigcirc$ poema estabelece relação analógica entre a atividade da poeta, a atividade do bicho de seda e o envolvimento erótico.

O amor é enrediço, tecedor de entrechos e envolve os sujeitos em entrelaços e emaranhados, aspecto indicado na sua aproximação com o bicho da seda. As imagens poéticas indicam a metamorfose da poeta em personagem clássica e a transformação da personagem secundária em principal, consequentemente, complexa. $\bigcirc$ tema central não são mais os feitos heroicos e grandiosos do esposo, mas o sentimento amoroso que os unia, visto sob uma nova perspectiva. "Bicho de seda" é o poema que abre A alquimia dos nós e que, porventura, também fecha a obra, sugerindo mais uma vez a atividade circular realizada pela tecelã na volta dada pelo fio. Os fios que atravessam essa obra são os fios de Eros, conforme expresso no poema de Safo de Lesbos que abre este estudo.

As epígrafes no livro de Yêda Schmaltz, por sua vez, situam-se em um jogo complexo, uma vez que a autora interfere nos textos originais, transformando-os, antes de o contexto do discurso subsequente fazê-lo. No núcleo fabular de "Fios (O livro de Penélope)", a heroína inicia a narração de sua "odisseia lírica" pelo casamento com Ulisses, mais precisamente a noite de núpcias do casal. O poema com o título estratégico "As núpcias" é aberto com a epígrafe homérica "Penélope que despose aquele que mais lhe der, e que o destino assinalar" (SCHMALTZ, 1979, p. 23). 
A alquimia dos nós, como quase todas as obras de Yêda Schmaltz, é saturada de citações diretas de outros textos, isto é, nos livros da autora encontra-se um grande número de excertos de outros autores precedendo seus textos, mas as citações de natureza epigráfica antecedendo os poemas são mais comedidas. Em "O livro de Penélope", somente o primeiro poema é epigrafado, sendo essa justamente retirada da Odisseia, de Homero, obra que servirá de mote para a construção dos poemas do interior dessa primeira parte. A epígrafe, anteriormente transcrita, é originária do episódio em que os pretendentes tentam forçar Penélope a considerar que Ulisses estava morto, devido ao longo tempo sem notícias do herói, e por isso ela deveria escolher um novo esposo entre os pretendentes. No contexto do poema, a epígrafe tende a atribuir certa liberdade à escolha de Penélope, enquanto no contexto original é justamente o contrário, a escolha da heroína é compulsória, a recuperação constitui, portanto, uma ironia à limitação imposta às mulheres em diferentes contextos de sociedades eminentemente patriarcais. Tal ironia já configura um traço distintivo da Penélope yediana em relação à personagem da tradição literária, pois a personagem que silenciou seus anseios na maior parte da obra homérica surge comunicando, em "As núpcias", suas experiências eróticas com Ulisses e ostentando os prazeres advindos dessa relação. Assim, estabelecida a epígrafe na abertura do poema, tende-se a reconhecer a voz nos versos seguintes como pertencente à Penélope, o que é reforçado pelo fato de tais versos iniciarem-se com um verbo em primeira pessoa:

Despi as roupas amplas
guarnecidas de laços
e passamanarias.
Vem amor,
a ti quero dar-me.
A ti quero dar
o meu corpo
e a minha poesia
- únicos bens
de que disponho:
tudo o que sou
e o que componho.
[...]
(SCHMALTZ, 1979, p. 23)

A dicção de Penélope é pressentida não só devido à interrelação epigráfica, mas também às escolhas lexicais e às imagens apresentadas. Note-se que a vestimenta que aparece é "ampla", enfeitada ou provida de elementos usados em vestes da antiguidade. As passamanarias são um dos acessórios mais antigos usados em roupas femininas, também denominadas de "passamanes", são fios dourados ou coloridos que servem de guarnição a

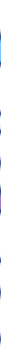


vestidos, a fim de deixá-los mais sofisticados. Tais elementos constroem a imagem de uma mulher da antiguidade, pertencente a certa estirpe, como outrora foi Penélope, esposa do rei de Ítaca. O uso dos pronomes em segunda pessoa circunscreve, ainda, a voz lírica ao passado e lhe acrescenta um caráter solene por ser próprio de um uso infrequente, presente ,de forma excepcional, na poesia clássica.

Estabelecida a analogia entre a voz lírica do livro e a personagem Penélope, da Odisseia, é possível perceber certa ironia na relação da epígrafe homérica e os versos que subseguem, porque o excerto homérico, que refletia as sucessivas violências sofridas pela mulher, tem essa conotação convertida em ostensivo erotismo, quadro que integra as vivências da voz lírica. Assim, pode-se perceber que no interior de "Fios (O livro de Penélope)" há um uso inusitado das citações diretas, pois a autora transforma os excertos retirados da Odisseia. No caso da epígrafe de "As núpcias", o sentido original é corrompido, mas nos demais a situação é mais complexa.

Ao final da página que abre a primeira parte do livro aparece a epígrafe "Que não se percam todos estes fios", atribuída a Homero. O trecho constitui uma transcontextualização da fala de Antino na Rapsódia II, da epopeia grega. Antino cita em seu discurso a fala de Penélope aos pretendentes: "Jovens, meus pretendentes, o divino Ulisses morreu; mas, apesar do desejo que tendes de apressar meu matrimônio, aguardai que termine este véu, para que não quedem inutilizados todos estes fios" (HOMERO, 2003, p. 31). O trecho em destaque será transformado pela autora na epígrafe atribuída a Homero, ao final da página 21, de A alquimia dos nós. Contudo, o excerto não é completamente pertencente ao poeta grego, porque sofreu interferência da poeta goiana. Com isso, nessa página se encontra o gesto inventivo de que lança mão a autora na construção das epígrafes que ilustram o livro, no qual são misturados textos dela e de outros escritores e textos que são a simbiose de um e outro. Isto é, cerzidos ao discurso moderno, encontram-se textos do passado urdindo a trama da Penélope reinventada.

Os excertos atribuídos a Homero tornam-se discursos complementares ao discurso da poeta. Desse modo, os fios que não devem ser perdidos podem ser reconhecidos como as temáticas abordadas no livro, o amor total e a arte escrita. A autora empreende, através dessa estratégia, uma concordância entre o velho e o novo, nessa concordância a obra do passado é alterada pela obra moderna. Processo semelhante ocorre na terceira epígrafe da seção:

Um deus inspirou-me a ideia de armar, em meu aposento, um grande tear e ir tecendo um véu sutil e comprido em máquina lanofix, ponto de meia, em máquina lettera 22, ponto e vírgula. [...] Desde então, durante o dia, lidava na imensa teia; e, de noite, à luz de tochas, desmanchava-a. Na verdade, de dia eu lidava, de noite é que eu sonhava. Por esta forma, consegui encobrir o meu ardil e trazer enganados os meus pretendentes. (SCHMALTZ, 1979, p. 47, grifos nossos)

Marcamos em itálico no excerto acima os trechos que a autora inseriu no texto de Homero para, assim, evidenciar que as interferências oferecem ao discurso antigo,

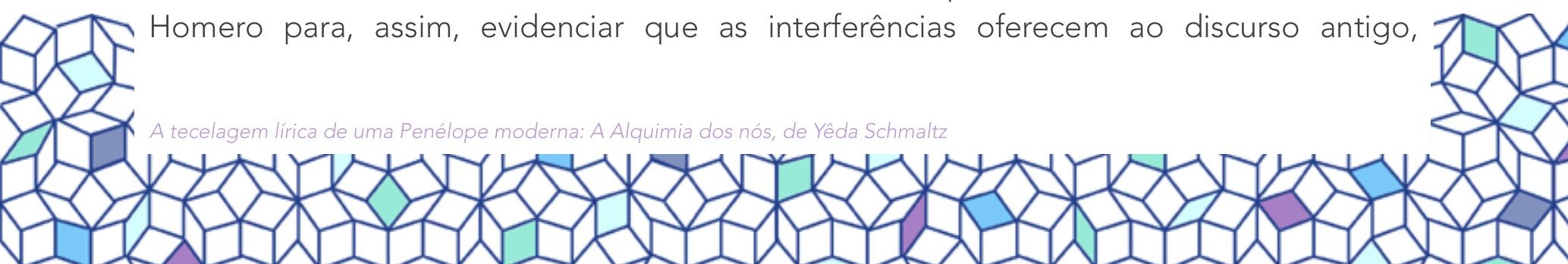


predominantemente masculino, uma perspectiva feminina e feminista porque expressa o percurso de uma mulher que se descobre através do trabalho da costureira e/ou da poeta. Se na Odisseia Penélope fala diretamente somente quando Ulisses retorna, na reinvenção criativa da autora goiana a discursividade da personagem torna-se uma constante, algo asseverado pelas epígrafes que são justamente falas de Penélope. Das cinco epígrafes constantes na primeira parte do livro, cinco pertencem a Penélope, e a última constitui a fala, também transformada, de Euricléia (transcrita adiante) anunciando o retorno de Ulisses e asseverando a nova dimensão tomada pela Penélope lírica.

As quatro epígrafes em que Penélope situa-se como a enunciadora, o trabalho artesanal da personagem da antiguidade encontra correspondências com a atividade da poeta. Isto é, na interferência, a autora estabelece um jogo dúbio, dubiedade que atravessa toda a obra, acerca do trabalho realizado pela voz lírica, pois ela refere-se tanto ao trabalho com o tecido quanto com o texto poético, tratando tais atividades de modo indistinto. Isso ocorre porque, conforme consta no trecho anteriormente citado, entre os instrumentos da costureira encontra-se o "ponto e vírgula", atributo próprio da escrita. Além disso, tal excerto encontra-se antecedido e precedido de textos que adotam o tecido como metáfora do fazer poético e da entrevista erótica, a exemplo de "O bordado", "O tecido", "O tapete", "Tear" e "Agulha". Este último poema merece atenção especial devido à complexidade que encerra.

No poema "Agulha" (SCHMALTZ, 1979, p. 50-51), parece surgir uma exacerbação do desejo sexual ao ponto de ocorrer a erotização de objetos ligados ao trabalho da costureira, o que é ocasionado pela abstinência imposta à heroína pela ausência do esposo. A temática da composição centra-se em uma particularidade do anseio erótico, o misto de dor e prazer. Nesse anseio, a voz lírica encontra inusitadas correspondências entre o homem amado e o instrumento utilizado em seu labor, através dessa correspondência se manifesta o erotismo da composição, dado que, nela, não se tem materializada a imagem de um amante, e a experiência erótica é desentranhada do êxtase solitário:

\section{Agulha}

Esta agulha,

para que serve?

Para coser

e ferir.

O poema parte da tentativa de esclarecer o caráter pragmático da agulha. Na primeira estrofe, a conclusão já é de que o objeto serve para coser e ferir. Com isso, a estrofe inicial não distorce o sentido primeiro do material enfocado, porque de fato a agulha costura e fere o tecido que atravessa, mas no decorrer do poema esse objeto sofrerá reiterada indagação sobre sua condição. A insistência das perguntas "o que é a agulha?" "para que serve a agulha?", pairando sobre o poema, culmina por colocar em suspensão a própria natureza e funcionalidade do instrumento. Com isso, embora a estrofe inicial realize um

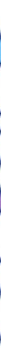


questionamento dentro dos padrões de normalidade da linguagem cotidiana, ela inicia um trabalho de (re)colocar a terminologia fora dos lugares comuns. A estrofe seguinte encaminha-se para uma definição poética do objeto de modo a intensificar essa faceta:

Imantada agulha
perfura
entrando pela pele
e navegando
para o encarnado
lugar.

A estrofe acima foge completamente da abertura prosaica dos versos iniciais ao se embrenhar pela dicção poética, constituída a partir das escolhas lexicais e do contorno rítmico que leva a atenção do leitor a sobrecair sobre a funcionalidade dúbia da agulha. $O$ termo que abre essa estrofe é o principal responsável por tornar ambígua a imagem do instrumento, posto que o objeto descrito passa a "imanizar" características que destoam da sua função pragmática. "Imantar" é atribuir força magnética a um corpo. A "agulha imantada" atrai para si conotações não só do objeto que atravessa o tecido, levando a linha para as profundezas da costura, mas de penetração sexual, uma vez que o léxico ali presente ("perfura", "entrando pela pele", "navegando", "encarnado lugar"), parece dizer mais a respeito da penetração amorosa do que da urdidura do tecido. O verbo "navegar", não raro empregado nas composições do livro, surge enriquecido, nesse contexto, sugerindo a cadência rítmica da cópula. Os versos seguintes avançam na voltagem erótica da composição:

\author{
Nem vejo \\ as minhas mãos: \\ meus olhos cegos, \\ no palheiro do mundo, \\ enevoados, \\ seguem o fio \\ do bailado \\ no brilho da agulha.
}

Na terceira estrofe, comunica-se diretamente o trabalho manual com o tecido, no qual a agulha atua frenética e mecanicamente, de modo que os olhos da artesã não podem apreender. A simbologia das "mãos que trabalham freneticamente" e do "bailado" constante na atividade descrita pode sugerir desenvolvimento sexual solitário, porque aludem ao êxtase sexual e, ainda, à cadência da cópula sem a presença de um parceiro, algo reiterado pela ausência de Ulisses. $\bigcirc$ quarto verso, tratando das mãos perdidas "no palheiro do mundo", reconstrói o dito popular "uma agulha no palheiro", referente à impossibilidade de se encontrar algo pequeno em uma grande confusão, aludindo ao órgão genital feminino,

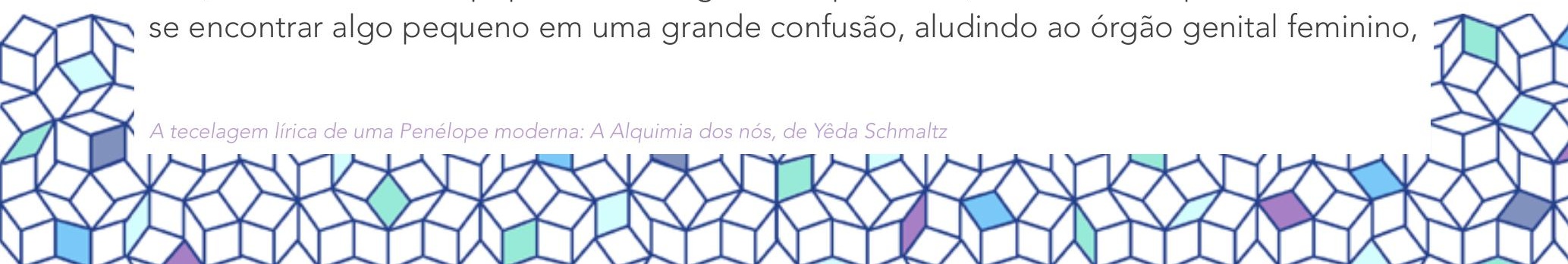


"palheiro" para o qual a agulha é atraída. Esse verso parece mencionar a genitália feminina devido à pequena dimensão que os órgãos sexuais ocupam no corpo humano em oposição à grande dimensão tomada na vida dos sujeitos pelo desejo erótico. "Palheiro" indica não só "o depósito de palha", como no dito popular supracitado, mas também "vísceras", "intestinos", "centro", "interior", o que pode servir para esclarecer a ideia, contida no verso, de que os órgãos sexuais figuram como centro, pivô e espaço de convergência da intimidade humana. Além disso, a expressão "palheiro do mundo" assume conotações referentes à capacidade geradora (do mundo), característico das mulheres.

A segunda e a terceira estrofes são os excertos da composição que mais colocam em evidência a angústia carnal representada no poema. Nelas, vislumbra-se a posse amorosa, escamoteada por uma linguagem poética que foge à predisposição de discutir questões relativas ao sexo. Estando essa entrevista amorosa disfarçada sob o pressuposto de dizer sem o fazê-lo, comunicar através de termos "enevoados", pode-se entrever na terceira estrofe indicação de sexo solitário, através das mãos e dos olhos cegos focados "no palheiro do mundo". Também esses olhos "cegos", pelo frenesi erótico, seguem o fio da agulha, em uma sugestão de que a presença do membro fálico ocorre somente no plano onírico. A quarta estrofe divaga em torno desse tema, razão de aparecer marcada entre parênteses:

(Se para emendar
é preciso primeiro
perfurar,
é preciso sofrer
pra se poder
amar?)

A estrofe considera a relação intrínseca do sofrimento com o sentimento amoroso. $\bigcirc$ excurso da poeta configura uma espécie de recuo por ter as estrofes anteriores avançado demasiadamente para a tematização da angústia carnal. Dor e prazer são considerados, então, como características imbricadas à realização amorosa através da pergunta retórica contida na estrofe. A quinta estrofe começa lançando mão da reiteração dos versos que abriram o poema:
Esta agulha,
para que serve
se fere
e não tem linha?
E seria esta agulha
mesmo minha?

À pausa subsegue, portanto, o retorno à pergunta insistente no poema ("Esta agulha para que serve?") prosseguindo em busca de sua determinação. A retomada intensifica a

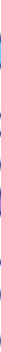


tematização da angústia carnal, que havia sofrido rompimento pela estrofe que procede na divagação do tema. Com isso, o erotismo sofre recrudescimento a partir da caracterização dessa agulha que não é agulha, porque não tem linha e fere de um modo que não corresponde à atuação do objeto utilizado na costura. A indagação final, na quinta estrofe, questiona se a agulha pertence ao eu lírico. Tal verso pode ser lido como uma forma de levar à frente, no âmbito do discurso, a imagem da sexualidade solitária, porque demonstra distanciamento entre a agulha (membro fálico) e o eu lírico, conduzindo ao entendimento de que a agulha que navega para "o encarnado lugar" o faz somente no plano da imaginação. As estrofes finais se desenvolvem de modo a se constituírem intensificações das imagens presentes na segunda e na terceira estrofes:

Perfurante agulha
do meu ser,
rainha destronada
e sem linha
- bainha.
Avesso da costura,
ante-agulha
desbordada,
instrumento perfurante
- espada.

A agulha se apresenta na penúltima estrofe como objeto que perfura o ser do sujeito lírico, sugerindo penetração material e imaterial, imagem plenamente erótica porque o envolvimento esboçado é carnal, passional e projetado para um mais além do erótico. Essa estrofe é concluída, por sua vez, através da contração rítmica entre os termos rainha/bainha, figurando como representações da feminilidade do eu lírico. A estrofe última do poema, em oposição à precedente, evocando a imagem da mulher, desenvolve a imagem do masculino através das construções metafóricas "avesso da costura", "instrumento perfurante" e "espada". Com isso, pode-se aventar a ideia de que a conjunção fálica da agulha, inicialmente representada no poema, prosseguiu para a ostensiva imagem viril da espada, o que vem confirmar a impetuosidade do desejo erótico na composição.

A linearidade de A alquimia dos nós corresponde à linearidade do fio e suas circunvoluções. Em "Fios (O livro de Penélope)", a trama central desenvolve-se sobre o fio do desejo, a mulher que fia e a espera do homem amado, envoltos em uma conjuntura poética. Assim, o fio assume caráter iniciático, como ocorre nos contos de fadas tradicionais, pois Penélope desposa Ulisses, passa pelo período de união plena do casal, sofre as intempéries típicas do relacionamento erótico, enfrenta provas que a levam a superar, notadamente a solidão e a limitação de seu espaço de circulação; tenta identificar-se com o ser amado e, por fim, frente à impossibilidade de restabelecimento de continuidade, corta o fio do desejo através

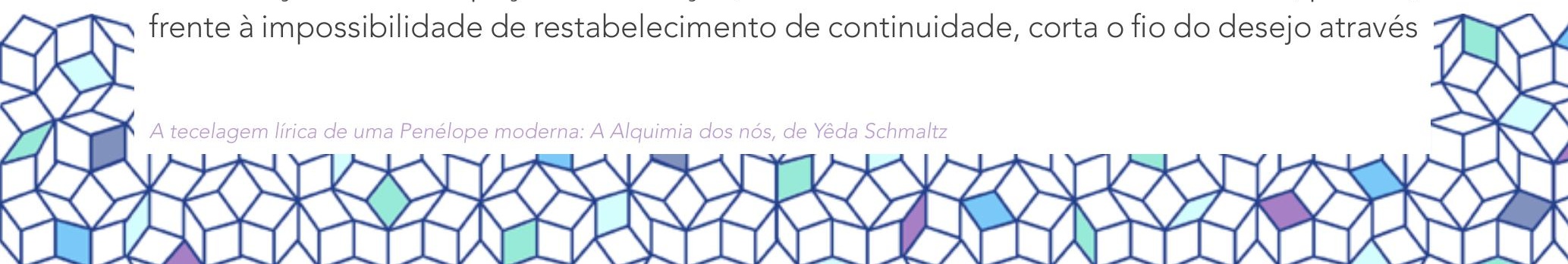


do recurso irônico, quando a imagem heroica de Ulisses é dessacralizada pelo poema que o apresenta como um homem "miúdo", "sem significado", menor do que qualquer um dos pretendentes. O desenrolar dos trabalhos da fiandeira, portanto, demarca a transformação da personagem central através dos acontecimentos que demonstram seu anseio por se libertar da figura opressora de Ulisses, para, enfim, encontrar-se livre para outras experiências amorosas. Nesse processo de descoberta de sua sexualidade, a experiência solitária ostensiva, porém sob um fino tratamento, em composições como "Sereias" e "A agulha", dentre outros, assinala o desenvolvimento afetivo e identitário da personagem reinventada.

Das narrativas orais da fonte popular e das demais recuperações do tema do fio em literatura, depreende-se a existência de uma simbologia sexual no trabalho da fiandeira, o que justifica essa correspondência entre o trabalho artesanal e o erotismo expresso na obra yediana. $\bigcirc$ traço de união entre trabalho manual e sexualidade decorre, em grande parte, do caráter iniciático assumido pela função, mas principalmente da fertilidade e da fecundidade que caracteriza as artesãs. As fiandeiras apresentadas na mitologia clássica e nos contos de fada relacionam o seu labor à promessa de chegada de um marido. A atividade preencheria esse espaço ou de alguma forma produziria a chegada do companheiro.

A atividade de fiar no interior da obra de Yêda assinala o percurso da poeta-artesã rumo à construção de seu próprio mundo e de sua identidade. Esse processo corresponde ao percurso das heroínas da mitologia e do conto maravilhoso, pois o linho desencadeia a ação e a partir dele elas fabricam as etapas de seu desenvolvimento pessoal. Isso pode ser percebido nos mitos de Aracne, Ariadne e Penélope, assim como nas lendas e contos populares, alguns sob o registro dos irmãos Grimm, sobretudo "As três fiandeiras", quando a operação com o fio confere novos atributos às personagens e por ele são inseridas em novas realidades; realidade que comumente significa encontro com o homem amado. Assim,

[a]tos e gestos próprios do trabalho de fiar são também provas de força, impostas como parte da formação de uma mulher, correspondendo a um período de autoformação afetiva e sexual. Trabalho que, não obstante a aparente imobilidade e a solidão em que se executa, afeta por inteiro o corpo da mulher-fiandeira, nele implantando o desejo. (LIBOREL, 1997, p. 375)

Nos poemas de Yêda Schmaltz, a mulher-fiandeira confunde-se com a mulher-poeta. A retomada da atividade da fiandeira na poesia yediana coaduna-se com um processo recorrente na poesia erótica de autoria feminina, a liberação da experiência do desejo nas coisas do cotidiano (SOARES, 1999), muitas vezes ironizando a ligação feita pela tradição patriarcal de certas atividades, domésticas em sua maioria, à mulher. Em Baco e Anas brasileiras (1985), de Yêda Schmaltz, boa parte dos recursos eróticos é desentranhada da atividade de cozinhar, preparar alimentos, o que figura como subversão da função precípua dessa atividade, porque as receitas são desenvolvidas não para alimentar a família, mas para ressaltarem os prazeres corpóreos vivenciados pelo eu lírico. Assim também ocorre com a

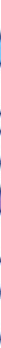


Penélope de A alquimia dos nós, pois a atividade de fiar reconstrói a sexualidade da heroína, subvertendo a função primeira da fiação, que seria criar vestimentas.

Em "Fios (O livro de Penélope)", o eixo fabular parte da noite de núpcias do casal central e a felicidade plena vivida no encontro erótico de Penélope e Ulisses. A partir do segundo poema, os fios intervêm na construção da metáfora erótica e na descrição das realidades das personagens épicas e líricas, a exemplo do que se apresenta em "Linha azul":

\author{
De joelhos \\ eu bordava \\ a barra da noite \\ com o meu branco \\ alinhavo. \\ teu olho \\ se debruçava \\ para a manhã \\ que eu, sem saber, \\ costurava.
}

E as nossas mãos

buscavam, sem sentir,

o nó que a linha

branca tramava.

Então,

pelo enredo da trama,

eu costurei

a minha boca

na tua boca

- um poeta me ama -

e a linha ficou azul,

cor de maçã.

(SCHMALTZ, 1979, p. 26)

O poema usa da metáfora da atividade da fiandeira para comunicar a felicidade vivenciada na união amorosa. Fato importante para indicar, na sequencia, a crise estabelecida em Penélope em decorrência da ausência do homem amado. As duas primeiras estrofes apresentam a heroína trabalhando na construção de um espaço ideal para o estabelecimento da relação amorosa, ao bordar de noite e de manhã, corroborando a simbologia em torno da fiandeira como geratriz e responsável por fiar o destino humano. Na terceira estrofe, encontram-se as mãos unidas em um "nó", reiterando a união feliz dos amantes,

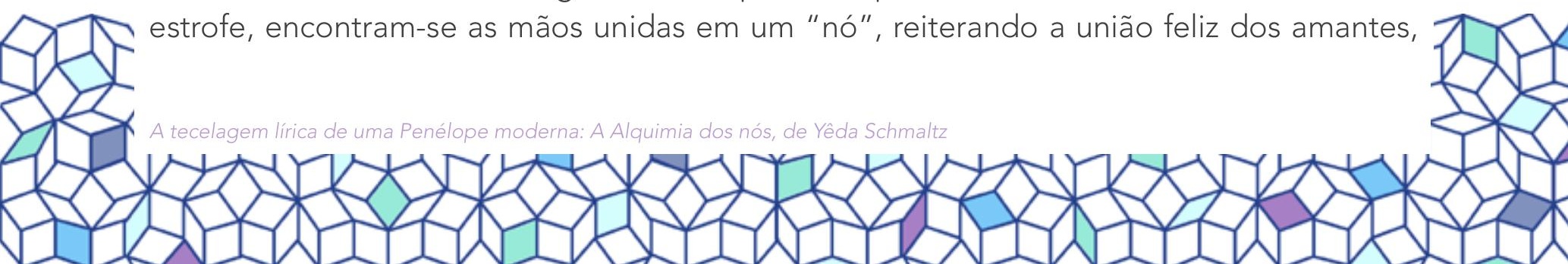


a recomposição do andrógino do mito platônico, o restabelecimento da continuidade. A quarta e última estrofe prossegue essa mesma apresentação com a imagem dos amantes com bocas costuradas uma à outra e uma linha azul que atravessa tal existência, mais uma vez reafirmando a ideia de união feliz.

"Linha azul" é um poema cuja perspectiva em muito se aproxima da desenvolvida por Marina Colasanti (1999), em "A moça tecelã", conto que abre o livro Doze reis e a moça no labirinto do vento. Assim como Colasanti, Yêda insere em sua obra aspectos típicos dos contos de fada no tratamento do percurso da Penélope reconfigurada. Colasanti, por sua vez, fixa sua produção na elaboração de contos maravilhosos modernos, enquanto Yêda recupera aspectos arquetípicos das personagens desse gênero na construção de sua poesia. Ambas retomam o fato de as mulheres serem responsáveis desde as eras mais remotas por fiar e nesse processo tornaram-se capazes de construir e destruir o objeto de seu labor, transformar o aspecto do meio em que vivem e, ainda, pelo fio reconstruir sua identidade. Também nessas escritoras, a fiandeira posiciona-se como a aranha ao construir sua teia e nela trabalhar para atrair o amante.

No conto de Marina Colasanti, encontramos um universo mágico, repleto de possibilidades, como é próprio do gênero maravilhoso. A tecelã cria através de seu labor o dia, a noite e o que serve às suas necessidades mais prementes. No recesso doméstico, a moça percebe sua condição solitária e, assim, tece um marido que, como os príncipes dos contos maravilhosos tradicionais, ingressa em sua vida de chapéu emplumado e como promessa de união perfeita. $O$ conflito estabelece-se quando o esposo toma consciência da capacidade criadora da tecelã e passa a exigir-lhe excessivos trabalhos, que a levam a tecer sem descanso os caprichos do marido. Exausta por ter-se tornado escrava das exigências do esposo, a artesã decide destecer tudo até o ponto de reencontrar-se novamente sozinha. Liberta, a tecelã volta a "ouvir" a chegada do sol e, com seus fios, a tecer as luzes de um novo dia, feliz com o retorno de sua condição solitária.

Em "A moça tecelã", a heroína, como a Penélope yediana, passa por um processo de autoafirmação identitária usando, como principal instrumento, os fios empregados em seu labor. "A fiandeira" de Yêda e "A moça tecelã" de Colasanti são figuras que destoam das artesãs do passado mitológico, porque atuam como agentes e transformadoras de sua realidade:

$[\ldots]$

Fiz tecidos de linho

e de púrpura

enquanto estava nua.

Mas meu amado

não temerá a neve

pois será vestido

de lã escarlate.

O meu amor é força

trançada nos dedos

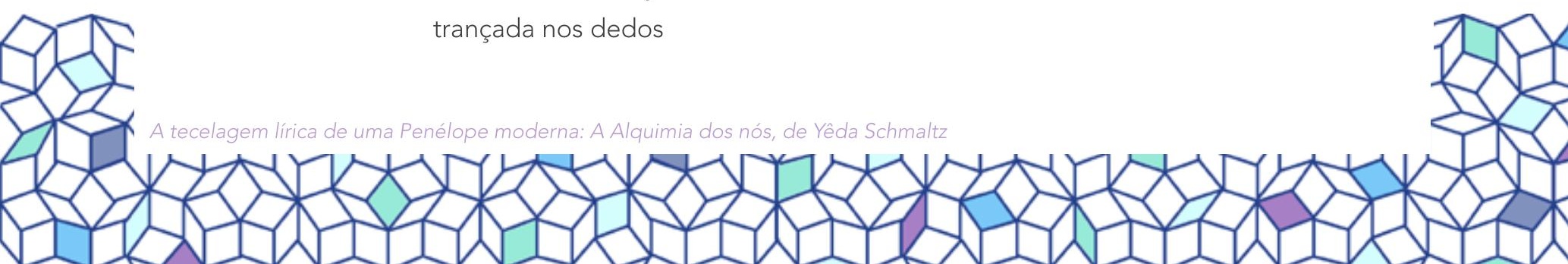


e despida eu me visto

de amor

e de dignidade.

(SCHMALTZ, 1979, p. 29)

Note-se que a força dos dedos da poeta-artesã, na composição acima, constrói a vestimenta do homem amado e o amor por eles vivido, numa evidente referência de que o amor é criação, invenção, conforme expresso em outros poemas da obra. Essa capacidade criadora da fiandeira é que oferece, nos versos iniciais, segurança ao homem amado. Ocorre, então, a inversão das perspectivas. No conto de fada tradicional, as heroínas esperam a chegada do amado protetor, algo semelhante à Penélope homérica. Na perspectiva moderna, apresentada tanto por Marina Colasanti quanto por Yêda Schmaltz, as artesãs são senhoras de seu destino, capazes de construir o amor e o homem amado, e, da mesma forma, desconstruí-los, bem como ainda desempenham função protetora, provedora em lugar dos companheiros. $\bigcirc$ amado nos versos yedianos não temerá a neve porque suas mãos urdiram "lã escarlate" para protegê-lo, a moça tecelã do conto, por sua vez, era a provedora do lar, aquela que propiciou o enriquecimento do esposo. Em A alquimia dos nós, esse aspecto é asseverado em outros momentos:

\section{Fios}

Recolheram-se os cordeiros

dos montes,

mas as minhas mãos hão de te dar

as vestes

No meu coração

há redes e laços,

mas as minhas mãos

são grilhões.

Eu amarrei as águas

na tua roupa

e encerrei os ventos

nos meus punhos:

minhas mãos te vestirão

de tempestade.

Meus fios:

ata-os aos seus dedos!

Desafios desarticulados...

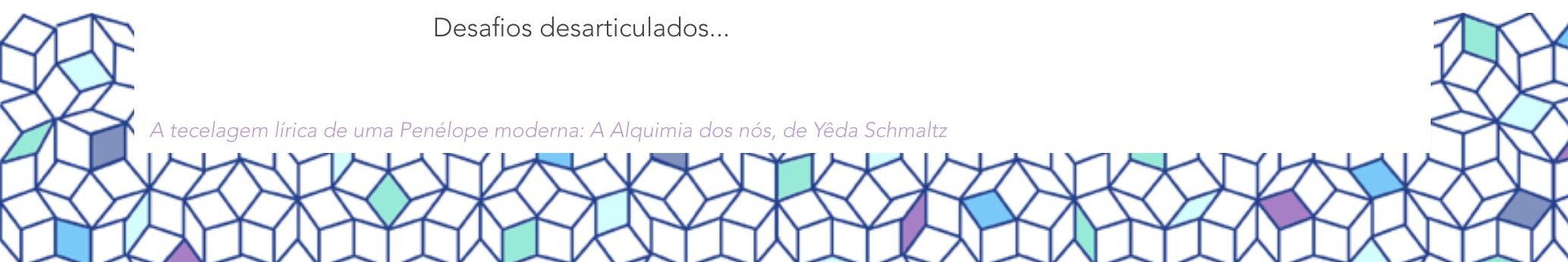


Meus fios finos de linho:

nada, seda.

(SCMALTZ, 1979, p. 30)

Os fios do trabalho da fiandeira são convocados para representar a impetuosidade do desejo do eu lírico em relação ao ser amado. Sendo o erotismo "sexualidade transfigurada" ou "metáfora da sexualidade", conforme definição de Octavio Paz (2001), os fios no poema acima servem para criar uma cerimônia erótico-verbal em torno do sentimento amoroso. Através da oferta das "vestes", do coração que enlaça e prende o amado, dos dedos que se atam, o eu lírico comunica o desejo de união com a figura amada. União que de fato ocorre, e o homem amado parece ser subjugado pelas atividades da fiandeira, dado ser ela quem lhe oferece as vestes e o prende a si. A união amorosa é simultaneamente espaço de prazer e prisão, sendo a fiandeira a figura dominante nesse contexto. Essa situação apresentada parece configurar uma superação extrema da mulher que, ao final, passa a situar-se em condição de igualdade (social e identitária) em relação ao homem.

Isso ocorre, notadamente, porque a dicção assumida nos versos não pertence necessariamente a Penélope, é a fala de Sulamita, do Cântico dos Cânticos, que ecoa na composição. Não só na supracitada, mas em diversas outras partes do livro. Esse fenômeno ocorre, sobretudo, em decorrência da cerimônia erótico-verbal que também caracteriza o discurso dos interlocutores no poema bíblico. Além disso, a Amada dialoga com o Amado em tom de igualdade, comunicando enfaticamente seus anseios eróticos. Interessante notar que nos Cânticos, a fala de Sulamita, a primeira enunciadora do poema, é aberta com uma solicitação ousada, os beijos do amado, e prossegue elogiando o corpo do homem amado:

\footnotetext{
Que me beije com beijos de sua boca!

Teus amores são melhores do que o vinho,

o odor dos teus perfumes é suave,

teu nome é como um óleo escorrendo,

e as donzelas se enamoram de ti...

(CÂN, 1, 2-3)
}

Essa exaltação do corpo do homem amado está presente nos poemas de Yêda Schmaltz na sequência de seis poemas com o título "A beleza do homem e seus apetrechos". Em tais composições a voz lírica tem em mira o corpo amado e sobre ele dispensando mirada eminentemente erótica, o que em muito aproxima os versos da escritora goiana da enunciadora do poema bíblico, porque não se furta a exaltar pela descrição o anseio de posse desse corpo. Interessante perceber que no processo de descrição do homem amado os apetrechos (sandálias, calça apertada, camisa branca) são primeiramente valorizados e, progressivamente, a voz lírica passa a tratar do aspecto físico (o bigode, a barba, os ladrilhos, os pelos) para, enfim, alcançar a imaterialidade do outro. Ao divisar esse aspecto transcendental do homem amado e exaltar a perfeição dele, o sujeito lírico ironicamente se

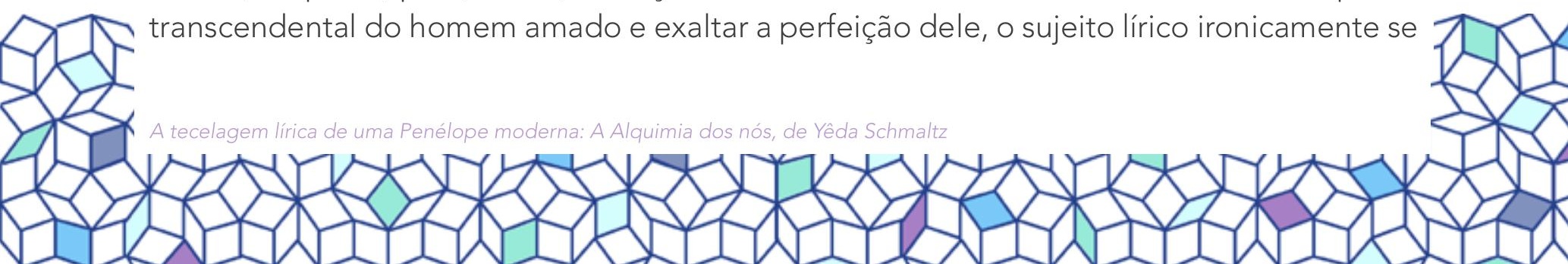


reconhece na pessoa amada, investindo no pressuposto de que o amor é fabulação, invenção e idealização, além de conter sua dose de narcisismo:

\author{
A beleza do homem \\ está no meu olhar \\ de amor \\ em ter amado \\ o homem.
}

\begin{abstract}
A beleza do homem
não é bem o seu talhe

ou sua voz macia:

é minha capacidade

de vê-lo em detalhe

e de multiplica-lo

em poesia.
\end{abstract}

\author{
A beleza do homem \\ sou eu. \\ Fui eu a escolhê-lo \\ e a julgá-lo eleito, \\ e em sendo eleito, \\ qualquer homem \\ seria o homem \\ perfeito. \\ [...] \\ (SCHMALTZ, 1979, p. 40)
}

O poema investe na caracterização do amor como mito, sendo o envolvimento amoroso equiparável à relação idílica. Outro aspecto que não pode ser desprezado é que tal pressuposto converge com as considerações de Octavio Paz (2001, p. 12) que notou ser o erotismo "sexualidade transfigurada: metáfora. A imaginação é o agente que move o ato erótico e o poético". Potencializados, o sexo transforma-se em cerimônia e rito, e a linguagem é transfigurada em ritmo e metáfora, assim o "erotismo é invenção, variação incessante" (PAZ, 2001 , p. 16). O homem amado do poema acima foi mitificado pelo olhar da amante, o que revela a relação entre desejo e fantasia.

Retomando a ideia de que amar e fantasiar se complementam, considere-se que a eroticidade constrói imagens difusas para os indivíduos emersos na violência erótica. Tocados por Eros, os sujeitos comumente não vislumbram a imagem objetiva, mas a reprodução fantasmagórica de simulacros eróticos. Desse modo, amar é sentir com a imaginação, e a arte de amar é também a de criar outros mundos e indivíduos hiper-reais. $O$ amor é o encontro

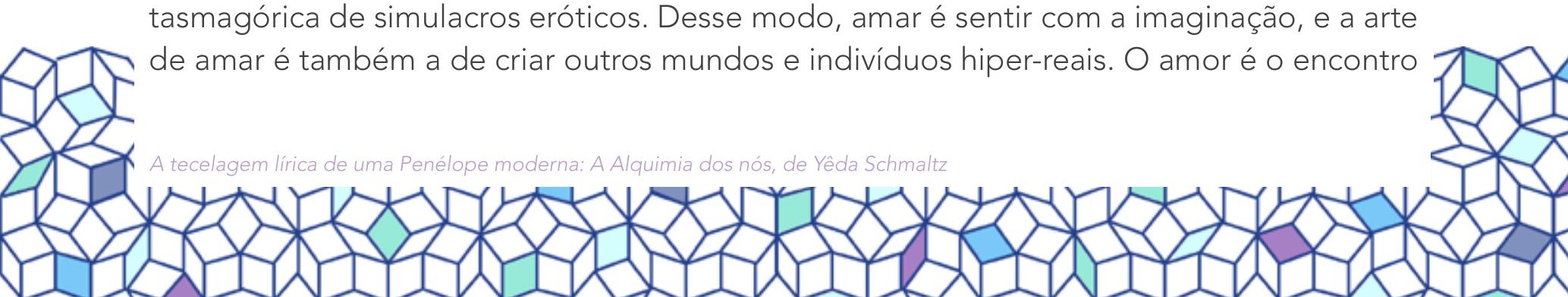


de realidades que se modelam a anseios, desejos, idealizações e sonhos dos sujeitos. Logo, a pessoa amada comunica mais encantos do que possui.

Esse é um aspecto percebido por Stendhal (2007, p. 14) ao ressaltar que "basta pensar em uma perfeição para vê-la em quem se ama". O escritor francês ressaltou, em Do amor, que o nascimento da paixão amorosa é acompanhado pela admiração pela pessoa amada, pela interlocução seguida de atração corporal, pela esperança em reter o objeto de desejo e, por fim, pela cristalização do sentimento. A cristalização para Stendhal é a exaltação das perfeições do objeto amado, por isso expressa um sintoma inicial da loucura de amor.

Ao asseverar a importância da imaginação no estabelecimento dos desatinos de amor, Stendhal parte do princípio de que um objeto amável deve parecer perfeito, assim, ao amarmos, encontramos a perfeição no objeto do desejo. Nesse processo, a imaginação deve fabular a "beleza" necessária para o amor, algo que converge com o mito de Eros, por sua vez originando a fórmula popular "o amor é cego". O sentimento, então, oferece o "verniz" de beleza necessário para o alumbramento do amante, justificando o pressuposto contido em Do amor de que a beleza do ser amado é uma coleção de desejos formados pelo imaginário do amante, pressuposto expresso no poema anteriormente citado.

A consideração de que a atração pelo homem amado configura uma fabulação, uma poetização da imagem dele, converge com a característica mais reiterada no interior de "Fios (O livro de Penélope)" em torno da heroína, a capacidade da poeta-artesã de fabricar, criar, inventar, urdir sua arte, seu enredo lírico e, até mesmo, o homem amado, de "multiplicá-lo em poesia".

O conflito, em "O livro de Penélope", instaura-se a partir do sexto poema, "Nós", quando Penélope percebe e sofre a ausência de Ulisses. Nesse poema, a personagem já se encontra trabalhando na mortalha para o sogro Laertes.

$[\ldots]$

E eu não me conformo.

- Sede instável -

Conformei em nós

pela costura

o nós que é singular.

(- Ah, eu não quero,

mas preciso desmanchar!)

- A água é doce -

Somente pelos nós

valeu a pena

costurar.

(SCHMALTZ, 1979, p. 33) 
O eu lírico surge no poema indicando seu desconforto pela ausência do homem amado, a costura aludindo à mortalha figura como um vínculo ainda mantido entre Penélope e Ulisses. A solidão da heroína é entrevista na metáfora do "nó singular", enquanto a última estrofe apresenta a heroína desfazendo a tessitura por ela construída, à revelia de sua vontade, e concluindo que a união feliz com Ulisses no passado oferece sentido às artimanhas da artesã. Esse poema, por sua vez, é um exemplo da reinvenção da Penélope lírica em relação à Penélope épica. Em Homero, Penélope é a esposa conformada com o distanciamento do marido; somente na Rapsódia XXIII lança a Ulisses as recriminações pelos males que sofreu. "Nós" é o primeiro poema de "Fios ( $O$ livro de Penélope)" que indica diretamente o afastamento do homem amado, e já nele a esposa se apresenta inconformada pela ausência do esposo.

Após a sequência de poemas em louvação à beleza do homem amado, surge a heroína vacilante em relação aos sentimentos nutridos pelo esposo, ao ponto de os nós de outrora se encontrarem "esgarçados":

\title{
Fio da meada
}

\author{
Impotente, \\ vejo soltas \\ as amarras dessa nau \\ e os laços um a um \\ a se quebrarem.
}

E sinto o lento,

o fatal desgaste

dos fios sustentantes

deste amor

(os fios que inventaste).

Já pende um único fio

e vai se esgarçando,

se esgarçando: cedeu.

O amar se fez

ao mar.

Fio da meada

de uma história.

Esquecer-te?

(Ao tempo que vivi

à beira dos teus

tantos olhos?)

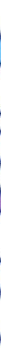




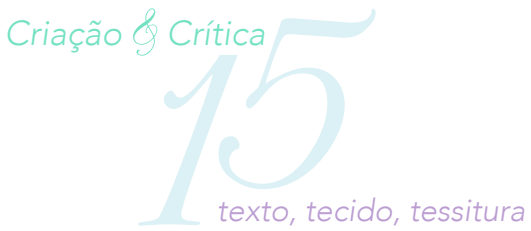

Bem sabes:

não é questão

de memória.

(Talvez da minha impotência

em ser fio de prisão

é que nasça a minha glória.

- Tão vário, tão esgarçado

é o nosso coração...).

(SCHMALTZ, 1979, p. 41)

Esse poema, que desde o título indica relação entre a fiação e a palavra escrita, abre espaço para um desprendimento de Penélope da figura de Ulisses. A partir de então o trabalho artesanal passa a ocupar todas as atenções da personagem central em poemas que usam o produto da fiação como metáfora do fazer poético, como "O bordado", "O tecido" e "O tapete". O amante começa a se perder na memória da esposa que chega a indagar no poema seguinte: "E tu, Ulisses, cheiravas bem?", "E tu, Ulisses,/ ainda estás preso/ na outra ponta?" (SCHMALTZ, 1979, p. 42). Tais composições assinalam o processo de crise pelo qual Penélope passa na ausência de Ulisses, a tensão decorre, conforme expresso na metáfora do fio que vai se esgarçando, do amor da heroína pelo esposo que começa a se afrouxar.

Em "Fio da meada", o arrefecimento dos sentimentos de Penélope pelo esposo é comunicado usando-se da evocação de imagens da Odisseia, mais precisamente a décima segunda rapsódia, quando Zeus desencadeia uma tempestade contra a nau de Ulisses, punição aos companheiros do herói, que haviam roubado o gado de Hélio. Do naufrágio, Ulisses é o único sobrevivente. A primeira estrofe do poema recupera o processo de naufrágio do barco, as cordas da nau que se desintegram correspondem ao desgaste dos fios que sustentam o amor de Penélope. Os versos "O amar se fezl ao mar" concluem a descrição do naufrágio e, por sua vez, indicam como elemento motivador do desenlace amoroso a saída do herói de ĺtaca pelo mar.

A fiação, nos poemas que têm por título o produto da atividade manual, insiste na correspondência entre o eu lírico, o tecido e a poesia, ao ponto de concluir: "Este tecido é a própria/ tecedeira" (SCHMALTZ, 1979, p. 45). Esses poemas sinalizam, ainda, passagem do tempo, posto que a fiação figura também como metáfora do desenrolar dos dias, e os instrumentos que ocupam o cotidiano do sujeito poético ("Tear", "Agulha", "Sereias") reforçam o desenvolvimento de uma exploração da sexualidade solitária, para preencher o vazio desses dias.

"O bordado de Penélope" é o poema que mais evidencia a correlação, irônica por sua vez, entre a escrita poética e a tessitura urdida pela personagem homérica, ao apresentar o título do poema, a página em branco e uma nota de rodapé dizendo que:

(O poema acima,

foi o mais comprido,

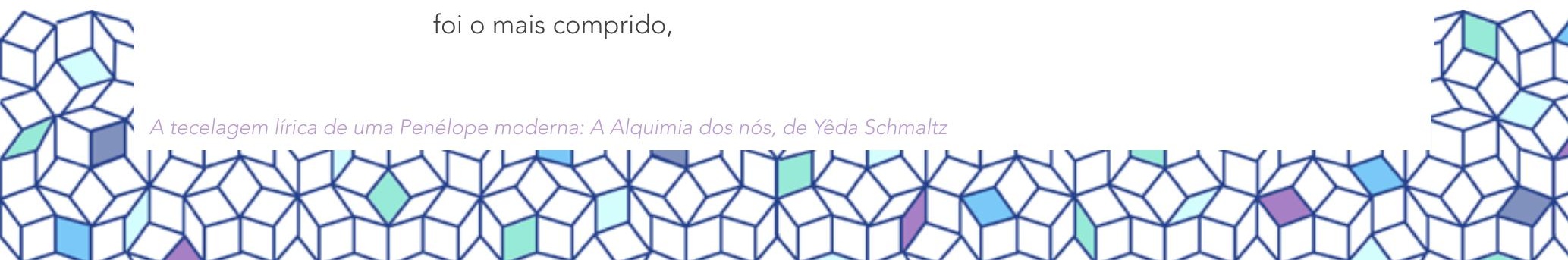


mais lindo e enternecido.

Foi escrito com ponto,

linha, foi tecido.

E era belo, colorido

como a manhã.

Mas foi apagado muitas,

tantas vezes!

- Comido pelas entranhas -

Com borracha "Pelikan".)

(SCHMALTZ, 1979, p. 55)

A escrita poética, nesse caso, apresenta-se como a mortalha construída por Penélope, costurada no período diurno e desmanchada noite afora. A borracha "Pelikan" assume a função das mãos que desmancham o produto do trabalho do eu lírico. O poema escrito e apagado estabelece correlação entre Penélope e a poeta, pois ambas trabalham na construção e na desconstrução do objeto de seu labor. A artimanha na construção desse poema, considerando que a nota constitui o próprio poema, depõe ainda sobre a busca, ostensiva na obra de Yêda, da beleza pura e total, efêmera e frágil, porque ameaçada por fatores diversos. $O$ eu lírico da obra busca incessantemente encontrar essa beleza pura e total no homem amado e na arte que produz, mas esse é um trabalho baldado pela impossibilidade de encontrá-los. Isso torna-se sintomático nos poemas que integram a longa sequência que tem em mira a beleza do homem amado. Frustrada por perceber que essa beleza era construção, imaginação e ilusão, por isso impossível, o eu lírico recusa o homem amado afirmando ser ele mais feio e miúdo do que qualquer um dos pretendentes. Cumprido o percurso de autoafirmação de Penélope, uma epígrafe retirada de Homero anuncia o retorno de Ulisses, parte desse excerto constitui a fala de Euricleia:

Acorda, Penélope, minha filha. Vem contemplar com teus olhos aquilo por que todos os dias ansiavas. Ulisses, chegou, tarde, é certo, mas já está em casa. É tua vez de ser gente e personagem: grite, dê ao mundo a lição de como se transforma o clássico em romântico, sem opção (SCHMALTZ, 1979, p. 57, grifos nossos) ${ }^{4}$.

Contrariamente ao enredo da epopeia, a heroína enfrenta dificuldades e é resistente em reconhecer o esposo e aceitá-lo de volta, o que é expresso na sequência de cinco poemas com o título "Espelho". Os três primeiros deles trazem o subtítulo "(Tentativa de reconhecimento)", o penúltimo é subintitulado "(Essência de reconhecimento)", e o último é a recusa da personagem feminina ao homem que se apresenta como Ulisses, por isso subintitulado "(Tentativa de desconhecimento)". Nesse aspecto, a primeira parte do livro de Yêda Schmaltz converge novamente com o desfecho do conto "A moça tecelã", de Marina Colasanti, pois nessas construções discursivas as personagens femininas passam por processos de autoafirmação identitária que culminam na recusa do esposo que trazia prejuízos

4 Pode-se perceber que Yêda Schmaltz utilizou a versão da Odisseia, de Homero (2003), traduzida por Antônio Pinto de Carvalho.

A tecelagem lírica de uma Penélope moderna: A Alquimia dos nós, de Yêda Schmaltz 
à existência plena delas. A valorização de si leva tanto a Penélope reinventada quanto a moça tecelã a optarem pela existência solitária.

O eixo fabular, no qual se encontra a heroína Penélope atualizada, delineia-se de modo mais preciso dentro de "Fios (O livro de Penélope)", mas ele é também perceptível ao longo do livro. Realizado o desenlace do casal mitológico no último poema da primeira parte, as subdivisões seguintes perseguem a temática erótica de modo mais ousado e violento. Outras figuras reais ou literárias surgem para indicar a transformação pela qual passa a imagem de Penélope.

Isso demonstra que, inobstante a autora dizer que o livro A alquimia dos nós continua no livro Atalanta, e a crítica interpretar isso como sinalizador do percurso da mulher na busca de autoafirmação, uma vez que Penélope é símbolo de docilidade e submissão, enquanto Atalanta de autonomia e independência, no primeiro livro por si só já ocorre uma reconfiguração da identidade de Penélope, rumo à independência. Esse processo, entretanto, não é simplesmente linear, é simultaneamente linear e circular, seguindo pressupostos da psicanálise junguiana rumo ao processo de individuação. De certa forma, Atalanta interfere ainda em A alquimia dos nós através da heroína homérica recuperada. A Penélope de Yêda já surge nas primeiras composições tomando consciência do seu corpo e seus desejos, e até o final da obra esse é um processo que gradativamente se intensifica. A ironia que perpassa a voz da Penélope yediana é outro sinal de que a personagem superou a situação de esposa submissa do rei de Ítaca. Além disso, a descrição e caracterização erótica do homem amado, nos versos que sofrem interferência da dicção de Sulamita, a ostentação de seus anseios libidinosos, são aspectos que destoam não só da Penélope clássica, mas também da mulher inserida em sociedades em que predominam o pensamento androcêntrico. É comum nesse contexto que somente o homem trate discursivamente sua sexualidade, à muIher cabe silenciar e reprimir seus anseios libidinosos, do contrário sofre retaliações morais. Ao comunicar a paixão amorosa e a intimidade feminina ostensivamente, o livro de Yêda Schmaltz assume caráter transgressivo e subversivo por reformular a condição da mulher diante de sua própria sexualidade.

\section{Referências bibliográficas}

A BÍBLIA DE JERUSALÉM. 10.ed. São Paulo: Paulus, 2001.

COLASANTI, Marina. Doze reis e a moça no labirinto do vento. 8. ed. São Paulo: Global, 1999. HOMERO. Odisseia. Trad. Antônio Pinto de Carvalho. São Paulo: Nova Cultural, 2003.

LIBOREL, Hughes. As fiandeiras. In.: BRUNEL, Pierre (org.). Dicionário de mitos literários. Trad. Carlos Sussekind...[et al]. Rio de Janeiro: José Olympio, 1997, p. 370-384.

LOPES, Cloves Trindade. Os nós de 'A alquimia dos nós'. Dissertação (Mestrado em Letras). Universidade Federal de Goiás, Goiânia, 1989.

MACHADO, Ana Maria. Texturas: sobre leituras e escritos. Rio de Janeiro: Nova Fronteira, 2001. PAZ, Octavio. A dupla chama: amor e erotismo. 4.ed. Trad. Wladir Dupont. São Paulo: Siciliano, 2001. 
SOARES, Angélica. A paixão emancipatória: vozes femininas da liberação do erotismo na poesia brasileira. Rio de Janeiro: Difel, 1999.

SCHMALTZ, Yêda. A alquimia dos nós. Goiânia: Secretaria de Educação e Cultura, 1979. Baco e Anas brasileiras. Rio de Janeiro: Achiamé, 1985.

Atalanta. Rio de Janeiro: José Olympio; Brasília, DF: INL, 1987.

STENDHAL. Do amor. Trad. Herculano Villa-Boas. Porto Alegre: L\&PM, 2007.

TELES, José Mendonça. Poesias e contos bacharéis II. Goiânia: Oriente, 1976.

TIETZMANN SILVA, Vera M. Penélope questionada - o tema do fio em Yêda Schmaltz. Signótica. Goiânia, ano II, janeiro/dezembro, 1990, p. 175-189.

Recebido em: 15/08/2015 Aceito em: 06/11/2015

Referência eletrônica: VIEIRA JÚNIOR, Paulo Antônio. A tecelagem lírica de uma Penélope moderna: A Alquimia dos nós, de Yêda Schmaltz. Criação \& Crítica, n. 15, p.136-159, dez. 2015. Disponível em: <http://revistas.usp.br/criacaoecritica>. Acesso em: dd mmm. aaaa.

A tecelagem lírica de uma Penélope moderna: A Alquimia dos nós, de Yêda Schmaltz

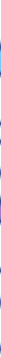

